Матеріали Всеукраїнської науково-практичної конференції «Актуальні питання діагностики, лікування, раціональної фармакотерапії, диспансеризації та реабілітації в практичі сімейного лікаря"

DOI

\title{
ФУНКЦІОНАЛЬНІ РЕЗЕРВИ СЕРЦЯ У СТУДЕНТІВ IV КУРСУ
}

๑Д. В. Козак, В. Б. Коваль, І. М. Салайда, В. В. Шафранський

ДВНЗ «Тернопільський державний медичний університет імені І. Я. Горбачевського мОЗ України»

Вступ. Здоров'я, за визначенням ВООЗ, це «стан цілковитого фізичного, психічного та соціального благополуччя». Академік Амосов вказує, що науковий підхід до поняття здоров'я повинен бути кількісним. Ймовірність виникнення і тяжкість перебігу хвороб обернено пропорційні «кількості здоров'я», або сумі «резервних потужностей» найважливіших органів і систем.

Мета дослідження. Визначити функціональні можливості серця у студентів четвертого курсу медичного факультету.

Матеріал і методи дослідження. Обстежено 134 студенти, з них 88 дівчат і 46 хлопців. Їм проведено одномоментну субмаксимальну пробу Руф'є, при якій визначали частоту серцевих скорочень (ЧСС) до навантаження (P1) і на1-й хв після навантаження (з 1 по 15 с (Р2) та з 45 по 60 с (Р3)). Оцінку результатів проводили за індексом Руф'є.

Результати й обговорення. Виявлено, що показники ЧСС до навантаження у юнаків становили $(67,2 \pm 3,48)$ уд/хв, у дівчат - $(68,9 \pm 4,25)$ уд/хв $(p<0,05)$ і коливалися в межах 60-92 уд/хв.
Безпосередньо після навантаження ЧСС у юнаків зросла в середньому до $(104,8 \pm 2,56)$ уд/хв (на $55,2 \%)$, у дівчат до $(104,2 \pm 3,42)$ уд/хв (на $52,8 \%$ ). Під кінець 1-ї хв у юнаків пульс утримувався в середньому на рівні $(86,7 \pm 2,87)$ уд/хв (129 \% відносно P1), у дівчат - $(82,4 \pm 2,18)(119,5$ \% відносно Р1).

Індекс Руф' $\epsilon$ у юнаків був 5,8, у дівчат - 6,0. За таблицею функціональних резервів серця це оцінюється як серце середньої людини, добре.

Висновки. Проба показала, що у осіб з однаковим вихідним пульсом може бути найрізноманітніша реакція на субмаксимальне навантаження, що свідчить про різні функціональні резерви серця. Спостерігається тенденція до росту ЧСС після навантаження по мірі зростання вихідного пульсу. У жінок, незважаючи на дещо вищі показники вихідної чСС, відсоток збільшення її після навантаження та під кінець 1-ї хв менший, ніж у чоловіків, що свідчить про кращі резервні можливості серця у студенток IV курсу. 